\title{
The Effect of Vegetation in Various Canyon Geometry on The Thermal Comfort of Jakarta
}

\section{Bayu Krisna Suryantara ${ }^{1}$, Jatmika Adi Suryabrata ${ }^{2}$, Alexander Rani Suryandono²}

\footnotetext{
${ }^{1}$ Student, Master of Architecture Engineering, Universitas Gadjah Mada

2 Lecturer, Departement of Architecture and Planning Engineering, Universitas Gadjah Mada
}

\author{
Article History \\ Received : 20 September 2018 \\ Accepted : 31 July 2019 \\ Published : 01 April 2019
}

\begin{abstract}
Buildings as absorber and heat reflectors can increase air temperature and as shaper formers can lower air temperature. However, both of these roles affect the extent of urban thermal environment, need to be studied through the form of canyon geometry creation of thermal comfort conditions outside space. The focus of this study is to examine how much the relationship between the vegetation and canyon geometry of urban thermal comfort in the humid tropics especially in Jakarta. This research used computer simulation method with hypothetic building object, to test how big influence of vegetation regulation on various canyon geometry to outdoor thermal comfort. Elements of canyon geometry that apply is aspect ratio and orientation. Because these two elements are the most influential elements in thermal comfort. The vegetation applied for this research is grass, greenroof extensive, intensive greenroof, greenwall and trees. Application of the vegetation in increasing thermal comfort is more effective than changing canyon geometry. However, the application of the vegetation will be more effective when applied in accordance with the canyon geometry.
\end{abstract}

Keywords: canyon geometry, vegetation, outdoor termal comfort

\section{Background of the Research}

Changes in the urban thermal environment are global issues that occur in big cities. This is indicated by the change in city air temperature. The change is inseparable from the physical changes of the city, especially on changes in land use that can change important factors in various cities and can lead to the occurrence of urban thermal phenomena known as Urban Heat Island (UHI).

The main cause of the UHI phenomenon is the replacement of natural land cover with pavement, buildings, and other infrastructure.

Correspondence:Bayu Krisna Suryantara

Student of the Master of Architecture Engineering, Gajah Mada University

E-mail: bayukrisnasuryantara1992@gmail.com
This change will reduce the number of trees and plants, thereby reducing the natural cooling effect of the evaporation and evaporation of water from the soil and leaves (evapotranspiration). Increasing the number of buildings height so that they form narrow lanes trapping hot air and inhibiting air flow (geometry effect). (Jusuf and Wang, 2007)

Several studies have discussed the effects of shadows on the thermal environment in an urban setting. (Shashua-Bar et al (2000); Bourbia et al (2004))

Sustainable urban design strategies must give high priority to microclimate and improvisation of urban thermal comfort. Open space in urban areas must be considered in relation to the shape of the building because 
The Effect of Vegetation in Various Canyon Geometry on The Thermal Comfort of Jakarta

Bayu Krisna Suryantara, Jatmika Adi Suryabrata, Alexander Rani Suryandono

it is complementary. Therefore, to create a comfortable urban microclimate, a harmonious balance between the shape of buildings and open space is needed. (Sharmin \& Steemers, 2013)

\section{Literature Review}

\section{Outdoor Thermal Comfort}

According to Soegijanto (1999) thermal comfort is influenced by several factors such as air temperature, radiation temperature, wind speed and humidity. It is also influenced by human factors themselves, such as in terms of dress, activity, body condition, and others. To calculate the thermal comfort of an outdoor space can use the thermal comfort index PET (physiologically equivalent temperature).

PET (physiologically equivalent temperature) which is one of the thermal indexes to assess the thermal comfort of outdoor spaces. This PET index is usually used to measure thermal comfort in a room, but lately it is widely used to calculate thermal comfort in outdoor spaces. The concept of PET calculation is the equation of the thermal balance of the human body revealed by Hoppe, 1999. The basis of the PET formula (physiologically equivalent temperature):

$\mathrm{M}+\mathrm{W}+\mathrm{R}+\mathrm{C}+\mathrm{ED}+\mathrm{ERe}+\mathrm{ESw}+\mathrm{S}=0$

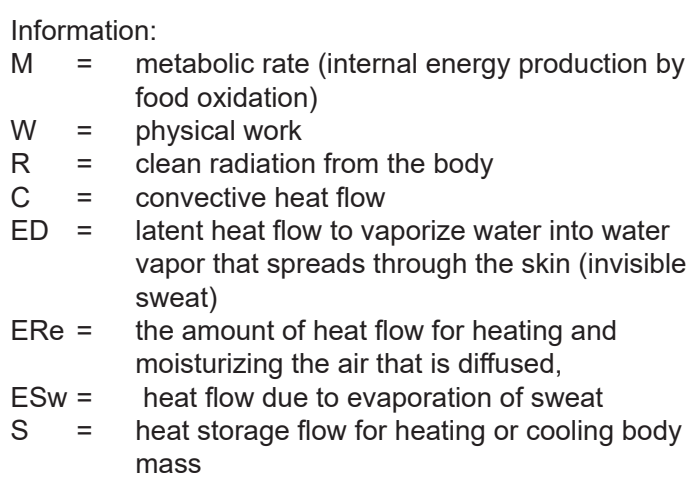

The results of research from Hwang et al (2011), Wei, Yang (2014), Paramita et al (2014) and Koerniawan et al (2015) show a comparison of the thermal comfort values of outdoor PET in tropical and subtropical countries, such as Taiwan, Cairo, Singapore and Indonesia. PET in Taiwan, Cairo and Singapore shows a maximum PET value of $30^{\circ} \mathrm{C}$ with case studies in parks, roads, universities, etc. While in Indonesia alone the PET value is quite high at $\pm 30-40{ }^{\circ} \mathrm{C}$ with case studies in towers and parks. This shows that the local macro climate has its own characteristics, so that it will create a micro climate that varies according to the characteristics of the local macro climate.

\section{Iklim Mikro}

Climate is a general condition of weather in a region at a certain time in a fairly long period of time, influenced by the characteristics of certain geographical locations. The environment formed from climate and geographical conditions can determine the type of climate and climate scale. Tropical climate types generally can be divided into two categories, namely: arid and humid tropics. In general, the climate scale is divided into three, namely macro climate, meso climate and microclimate.

This study focuses on showing the microclimate conditions in an urban landscape. Microclimate is associated with limited space, such as indoor spaces, roads, parks. This includes landscape features such as topography, soil characteristics and including the impact of human activities, such as the development of cities that emit heat and pollution as well as agricultural patterns, begin to have noticeable effects and cause significant and measurable differences in the local climate.

\section{Humid Tropical Climate}

The tropical climate is divided into two parts, namely a humid tropical climate and a dry tropical climate. The general characteristics of tropical climates are having high temperatures, daily average temperature and humidity are relatively constant, and the average monthly temperature range is around $1-3^{\circ} \mathrm{C}$. Humidity and rainfall is high for most of the year. Relative humidity is around $90 \%$. Wind conditions depend on the distance from the sea and can vary throughout the year. The sky is cloudy almost every time (Givoni, 1998).

Indonesia is included in the category of humid tropical climate with common characteristics are relatively hot air temperatures, high intensity of solar radiation and high humidity. More specific information about the characteristics of the humid tropical climate can be stated as follows: (Soegijanto, 1999). 
General characteristics about the humid tropical climate above, describe the climatic conditions of an urban. In a man-made environment can affect the microclimate which is different from the macro climate in the area, especially in this study is the city of Jakarta.

\section{Effect of Canyon Geometry on Thermal Comfort}

Buildings can provide different roles in an urban environment. Buildings as absorbent and reflecting heat can increase air temperature and as shading can reduce air temperature. However, both of these roles to the extent affecting the urban thermal environment, need to be examined through the configuration model of the urban space landscape and the imagery so that the creation of conditions of thermal comfort outside the room. The existence of an urban space landscape is expected to control the climate element, so that it can affect the condition of the urban thermal environment. Where the humid tropics have the characteristics of air temperature, air humidity and high intensity of solar radiation, as well as small wind speeds. Generally, the type of glass used for building facades is the type of clear glass, tinted glass and reflective glass, each of which has the ability to reflect light different suns.

An increased $\mathrm{H} / \mathrm{W}$ ratio can escalate reciprocity in urban corridors and a larger shade can reduce the amount of time compared to sunlit areas. It is possible to achieve greater shade with a higher $\mathrm{H} / \mathrm{W}$ ratio due to the reduction in direct solar radiation at the street level. Increased shade from a high ratio of height to width $(\mathrm{H} / \mathrm{W})$ can significantly reduce PET, and thus increase outdoor thermal comfort. (Emmanuel et al, 2007; Ali-Toudert and Mayer, 2007)

\section{Effect of Vegetation System on Thermal Comfort}

Increased H / W ratio can escalate thermal comfort is one of the most important comfort elements because it involves the condition of a comfortable room. The effect of building density and building height on the potential temperature, mean radiant temperature. Effect of several types of green areas (vegetation on the ground and on the roof) on temperature and mitigation of increased comfort. Vegetation on the ground and on the roof reduces summer temperatures, decreases indoor cooling loads, and increases outdoor comfort. The density and height of buildings in the city area affect the potential temperature, mean radiant temperature in most cases examined higher density causes higher temperatures with higher buildings affecting the cooling effect. Given the cooling effect of vegetation, seeing the difference depends on the amount of green area and type of vegetation.

There are three mechanical reasons for the strong relationship between vegetation structure and microclimate. First, the plant canopy absorbs, spreads and reflects incoming solar radiation, thereby reducing the amount of energy that penetrates the soil and air under the canopy. The amount of solar radiation absorbed by the plant's canopy depends on its Leaf Area Index (LAI), the density of the canopy, with high LAl, can block more than $95 \%$ of the light from reaching the earth's surface. Second, the plant canopy absorbs wind momentum and thus the wind speed decreases at in the canopy. Finally, the amount of water vapor that air can hold greatly depends on the temperature of the air. Therefore, in two environments with the same specific humidity (water vapor mass per unit mass of air) but with different air temperatures, the hot environment will have lower relative humidity than the cold environment.

\section{Research methods}

\section{Research methods}

This research uses a quantitative deductive method by modeling objects and simulations with the help of computer software. This simulation method is used because research on the desired object cannot be done directly because of the limitations of time, cost, and scale so that the model of the research object is created with computer software. According to Groat and Wang (2002), simulation research is useful when dealing with issues of scale and complexity.

\section{Research Instrument}

In this study, research tools or instruments were used to expedite the research process. The research tools or instruments are: Computer or laptop as hardware (hadrware) for the process of simulating and testing alternative models, 
The Effect of Vegetation in Various Canyon Geometry on The Thermal Comfort of Jakarta

Bayu Krisna Suryantara, Jatmika Adi Suryabrata, Alexander Rani Suryandono

83

analyzing research data, and preparing research reports. Software for testing model and analyzing research data. The software used in this research is Envi-met V4, and Microsof Office. ENVI-met is used to find out the thermal comfort of outdoor spaces in each of these landscape types. Output from ENVI-met stimulation: air temperature $\left({ }^{\circ} \mathrm{C}\right)$, air humidity $(\%)$, wind speed $(\mathrm{m} / \mathrm{s})$, radiation temperature $\left({ }^{\circ} \mathrm{C}\right)$ and PET $\left({ }^{\circ} \mathrm{C}\right)$. The process of using ENVI -met v.4.1 simulation and ENVI -met biomet v.1 The use of ENVI-met simulation program has been widely used by previous researchers to analyze microclimate conditions and thermal comfort of outdoor space in an urban area (Bruse, 2006; Ali-Toudert and Mayer, 2005; Johansson, 2006; Paramita and Fukuda, 2014). Based on the results of previous studies, it was mentioned that in addition to the advantages of ENVI-met simulation that can produce urban climatology, there are also some weaknesses. Bruse (2002) who is a programmer from ENVImet states that because differences in vertical long wave flux are not taken into account, this can result in a temperature difference of $2-4^{\circ}$ C.

\section{Locus and Research Focus}

The location of the study was conducted in the city of Jakarta. Jakarta is geographically located on the South Latitude between 6,2040 and 106,821o East Longitude. In general, the topography of the city of Jakarta has a height of about 10 meters above sea level. In this study using Jakarta macro climate data to see climate conditions in Jakarta throughout the year. The hottest month was chosen to show the hottest conditions in Jakarta.

The characteristics of the macro climate conditions of the city of Jakarta in the hottest month (November) because in November the position of the sun directly above the city of Jakarta so that it has a fairly high average temperature of $330 \mathrm{C}$, humidity is quite high at $71 \%$, wind direction 2400 average wind speed is quite low at $2 \mathrm{~m} / \mathrm{s}$ (Climate Consultant V6.0). This macro climate analysis is carried out to find out whether the existing climate data can indicate the condition of the outer space of Jakarta is in the thermal comfort zone or not.

\section{Building Geometry}

The building model of the building shape has been simplified to represent a simple straight volume. This allows us to generalize research replication that is characterized by the same aspect ratio. Each model consists of four building blocks and three roads (Ali-Toudert and Mayer, 2007) to generalize geometric proportions. The spatial domain height of the model is set 2.5 times the height of the building block.

Figure 1. Model 3d Envi-met

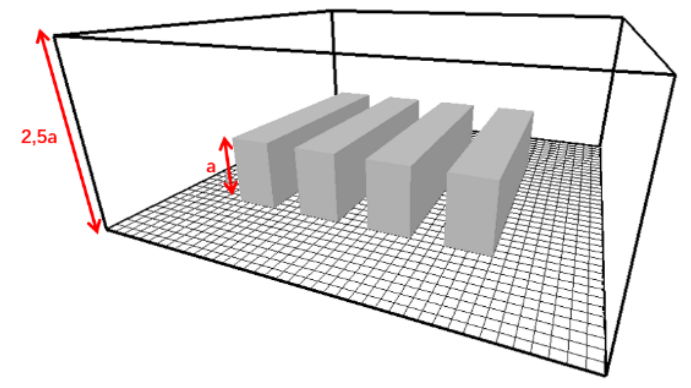

The distance between buildings / road width is $15 \mathrm{~m}$ and the building length is $100 \mathrm{~m}$. Building height adjusts to the $\mathrm{H} / \mathrm{W}$ ratio used (AliToudert and Mayer, 2006). Building materials are assumed to use precast concrete materials and road materials using asphalt. The point of measurement is in the middle of the building with a height of $1.5 \mathrm{~m}$ (average human height).

Figure 2. Geometry Building Research

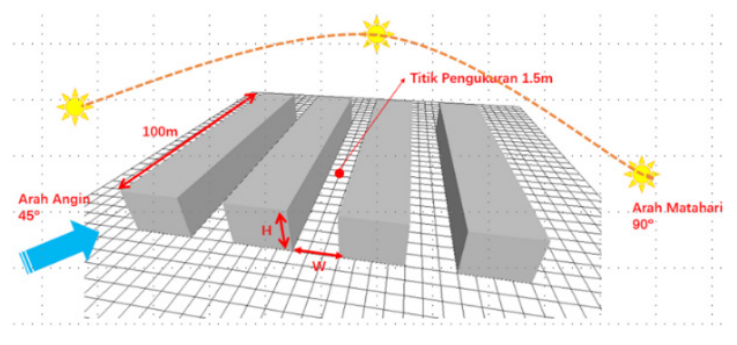

\section{Research Variable}

The dependent variable is the variable that is influenced by the independent variable and is the observed variable.

In this study the dependent variable to be examined, namely thermal conditions: The dependent variable is the variable that is influenced by the independent variable and is the observed variable. In this study the dependent variable that will be examined, namely the condition of Physiologically 
Equivalent Temperature (PET) which is influenced by

- $\quad$ Air temperature (Ta)

- Wind speed (Ws)

- Mean Radian Temperature (MRT)

- Humidity (Rh)

Independent variables are variables that affect the dependent variable. In this study the independent variables that will be examined, namely:

- Road / area orientation

Road / area orientation. To determine the orientation of the area is determined based on the orientation of the road. Orientations used in the study include $0^{\circ}$, $45^{\circ}, 90^{\circ}, 135^{\circ}$.

Figure 3. Independent Variable (Orientation)

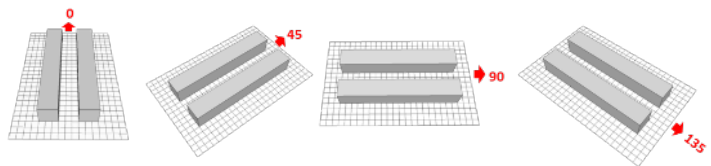

- H/W Ratio

Is a comparison of building heights and distances between buildings. The $\mathrm{H} / \mathrm{W}$ ratio used in this study is $\mathrm{H} / \mathrm{W}$ 0.5-2.

Figure 4. Independent Variable (H/W Ratio)

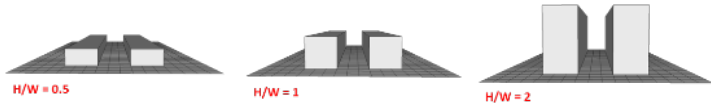

- Vegetation Layout

The initial green plot ratio study conducted by Jusuf \& Wong, (2009) using vegetation management technologies can be categorized as green roof (exstensive and intensive), green wall systems, planter boxes and modular plants that can be applied to: ground, podium, building and roof.

Figure 5. Independent Variable (Vegetation Layout)

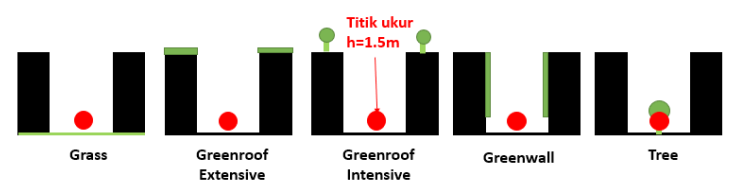

Vegetation elements are designed as follows:

(i) $0.5 \mathrm{~m}$ of grass in the middle of the road which covers $30 \%$ of the total surface width of the road,

(ii) extensive greenroof with $0.5 \mathrm{~m}$ grass height covering $30 \%$ of the entire roof area of the building.

(iii) greenroof intensive with $3 \mathrm{~m}$ height trees covering $30 \%$ of the total roof area of the building.

(iv) greenwall which covers $30 \%$ of the entire building facade. Assuming WWR of buildings is $70 \%$.

(v) a tree with a canopy diameter of $3 \mathrm{~m}$ at the center of the cordon extends along the length of the corridor with a $10 \mathrm{~m}$ tree spacing. A $10 \mathrm{~m}$ distance was chosen by adjusting the grid size in the Envi-met software.

(vi) a tree with a diameter of $6 \mathrm{~m}$ canopy in the middle of the cordier following the length of the corridor with a spacing of $10 \mathrm{~m}$. A $10 \mathrm{~m}$ distance was chosen by adjusting the grid size in the Envi-met software.

(vii) a tree with a canopy diameter of $9 \mathrm{~m}$ in the middle of the cordier extends to follow the length of the corridor with a $10 \mathrm{~m}$ tree spacing. A $10 \mathrm{~m}$ distance was chosen by adjusting the grid size in the Envi-met software.

\section{Input Variable}

The simulation takes the hottest month sample in Jakarta on November 9, 2017. It is carried out for 12 hours starting at 06.00-17.00. Meteorological data take from the climate of Jakarta in the hottest month, namely the speed of $2 \mathrm{~m} / \mathrm{s}$ in the direction of $240^{\circ}$, initial air temperature of $26.85^{\circ} \mathrm{C}$, specific humidity $7 \mathrm{~g} /$ $\mathrm{kg}$ with relative humidity $71 \%$.

\section{Results and Discussion}

\section{Effect of Urban Geometrics on Thermal Comfort}

The impact of road geometry, namely the aspect ratio $(\mathrm{H} / \mathrm{W})$ and road orientation, on outdoor thermal comfort, both have been known to have a considerable influence on microlimat changes in urban structures. Urban design parameters such as width, height and orientation can modify thermal bioclimate conditions in urban street corridors. The northeast-southwest orientation can reduce PET during the day more than any other scenario. $\mathrm{H} / \mathrm{W}$ to 2 ratios increase 
The Effect of Vegetation in Various Canyon Geometry on The Thermal Comfort of Jakarta

Bayu Krisna Suryantara, Jatmika Adi Suryabrata, Alexander Rani Suryandono

85

shade and increase thermal comfort during the day more than any other ratio (Emmanuel et al, 2007). The simulation takes one of the corridor samples that is rotated clockwise from $0^{\circ} 45^{\circ}$ $90^{\circ} 135^{\circ}$.

From the simulation results the relationship between canyon geometry and the role of vegetation on the value of thermal comfort shows that:

Figure 6. PET Calculation Results $\left({ }^{\circ} \mathrm{C}\right)$

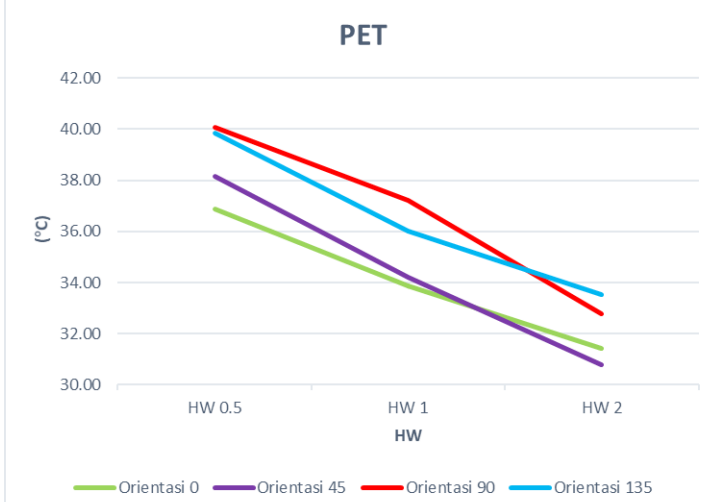

Tabel 1. Effect of Canyon Geometry on Thermal Comfort

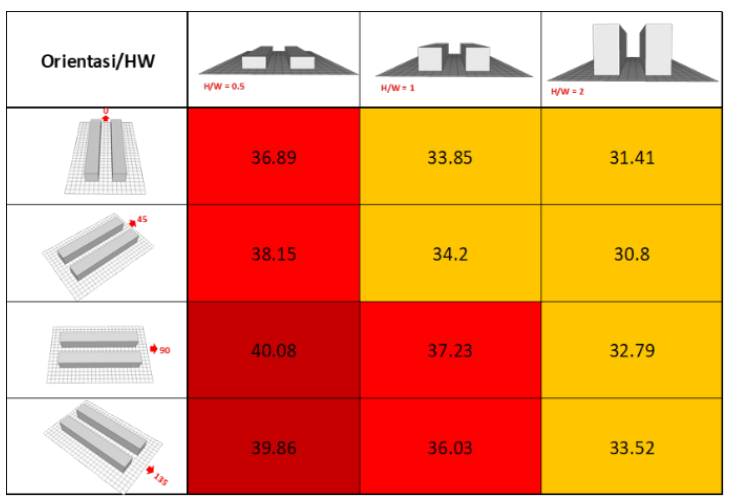

Standard PET (OC)

39-43 Hot

35-39 Warm

30-35 Slighty Warm

26-30 Neutral

The ratio of $\mathrm{H} / \mathrm{W}$ and orientation is one of the most influential factors in outdoor comfort. In corridors with low $\mathrm{H} / \mathrm{W}(\mathrm{H} / \mathrm{W}=0.5)$ is the most uncomfortable situation because in the pedestrian area the road gets long exposure to sunlight with minimal exposure and large heat storage on its surface. Corridors with high $\mathrm{H} / \mathrm{W}$ $(\mathrm{H} / \mathrm{W}=2)$ are the most comfortable conditions because they get a pretty good image from the surrounding buildings. Increasing the value of the $\mathrm{H} / \mathrm{W}$ ratio is very effective to reduce the value of PET, Ta and MRT. It also increases the value of wind speed (Ws) and relative humidity $(\mathrm{Rh})$. In the corridor with orientation $0 \mathrm{o}$ is the most comfortable orientation because it gets a pretty good shading from the surrounding buildings while the $90^{\circ}$ orientation is the most comfortable orientation because it gets the longest exposure to solar radiation compared to the other orientations. Corridors with high $\mathrm{H}$ / $\mathrm{W}$ ratio $(\mathrm{H} / \mathrm{W}=2)$ and orientation 00 are the most comfortable conditions compared to the $\mathrm{H}$ I W ratio and other orientations. In the corridors with orientation of $45^{\circ}$ and $90^{\circ}$, they have the highest wind speed (Ws) compared to other oerientasi.

\section{Effect of Vegetation System on Thermal Comfort}

The simulation is carried out by applying several vegetation scenarios such as the application of grass, extensive greenroof, green roof intensive, greenwall, and trees on several aspect ratios namely $\mathrm{H} / \mathrm{W}=0.5,1$ and 2 and some corridor orientation, namely orientation $0^{\circ}, 45^{\circ}, 90^{\circ}, 135^{\circ}$

Figure 7. PET Calculation Results

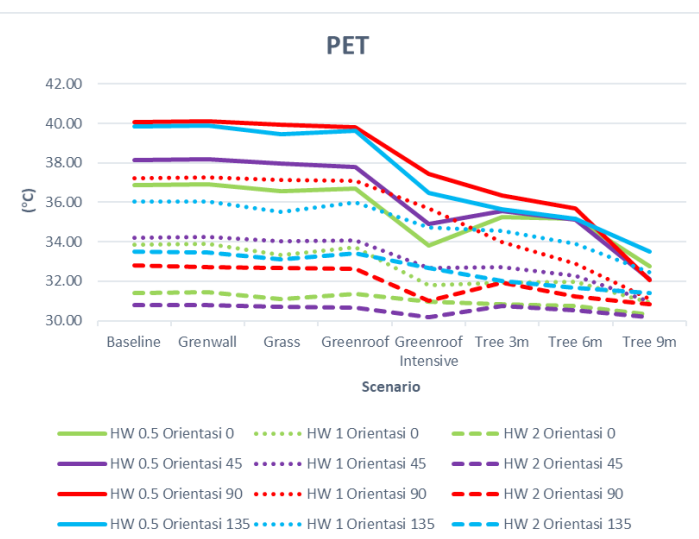

Application of vegetation in improving thermal comfort is more effective than changing canyon geometry. However, the application of vegetation will be more effective if it is applied in accordance with the geometry of the canyon. The relationship between canyon geometry and vegetation can be seen in the following matrix: 
Figure 8. Relation Matrix between Vegetation and Canyon Geometry

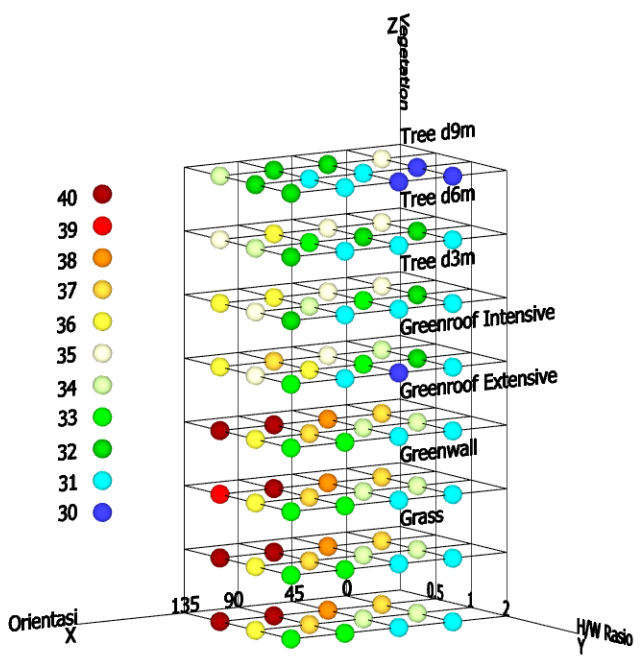

The effectiveness of the arrangement of vegetation in urban space is strongly influenced by canyon geometry, especially the $\mathrm{H} / \mathrm{W}$ ratio and orientation. Vegetation in the form of intensive greenroof and trees is more effectively applied at low $\mathrm{H} / \mathrm{W}=0.5$ compared to high $\mathrm{H}$ / $\mathrm{W}=2$. Road corridors with high $\mathrm{H} / \mathrm{W}$ ratio $(\mathrm{H} / \mathrm{W}$ = 2) $135^{\circ}$ orientation are strongly recommended the application of vegetation, especially trees with canopy wide ones. In corridors with high $\mathrm{H} / \mathrm{W}$ ratio, the application of vegetation is more effective for corridors with a orientation of 90 o compared to other orientations. The application of grass, greenroof and greenwall is less effective in increasing the comfort of outdoor space. The application of vegetation in the form of greenroof intensive and trees has a significant influence in decreasing the value of PET, Ta and MRT. For recommendations on the arrangement of vegetation based on canyon geometry can be seen in the Table 2 .

The most effective arrangement of vegetation is applied to canyons with low $\mathrm{H} / \mathrm{W}(\mathrm{H} / \mathrm{W}=$ $0.5)$ compared to canyons with high $\mathrm{H} / \mathrm{W}(\mathrm{H}$ / $W=2$ ). - Vegetation system in the form of greenwall (GW) is more effectively applied to canyons with high $\mathrm{H} / \mathrm{W}$ ratio $(\mathrm{H} / \mathrm{W}=2)$ with orientation of $90^{\circ}$ and $135^{\circ}$. ' The vegetation system in the form of grass $(G)$ is effectively applied to canyons with orientation of 00 and $135^{\circ}$. - The vegetation system in the form of greenroof intensive (GI) and extensive (GE) is most effectively applied at $45^{\circ}$ orientation. • The vegetation arrangement in the form of a tree $(\mathrm{T})$ is most effectively applied at the $90^{\circ}$ orientation.
Tabel 2. The relationship between the vegetation system and Canyon Geometry with Thermal Comfort

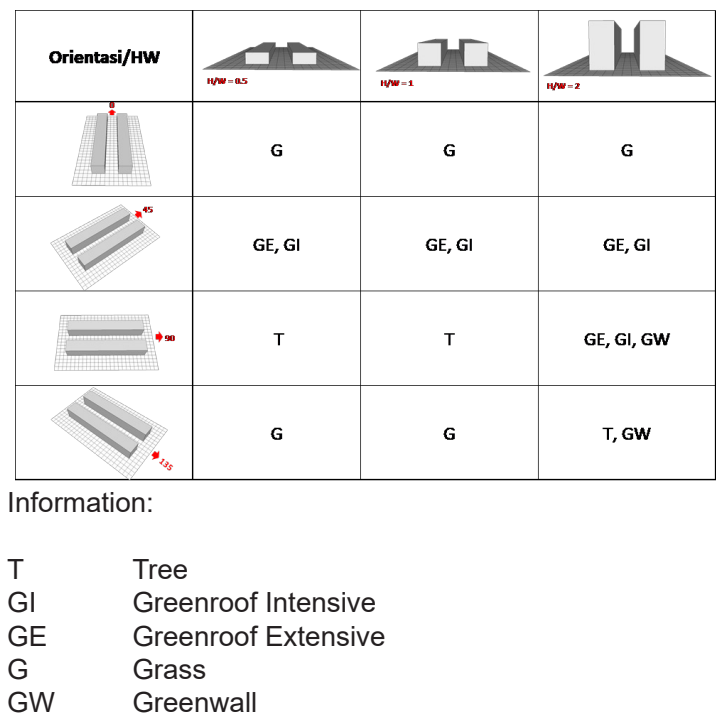

\section{Conclusion}

From the results of the simulations of the relationship between canyon geometry and vegetation order on thermal comfort, it can be concluded that the ratio of $\mathrm{H} / \mathrm{W}$ and orientation is one of the most influential factors in outdoor comfort. Increasing the $\mathrm{H} / \mathrm{W}$ ratio of $0.5-2$ gives a more significant effect on thermal comfort compared to the $\mathrm{H} / \mathrm{W}$ ratio > 2. In the corridor with low $\mathrm{H} / \mathrm{W}(\mathrm{H} / \mathrm{W}=0.5)$ is the most uncomfortable condition while the corridor with high $\mathrm{H} / \mathrm{W}(\mathrm{H} / \mathrm{W}=2)$ is the most comfortable condition because it gets a pretty good image from the surrounding buildings. In the corridor with orientation 00 is the most comfortable orientation because it gets a pretty good shading from the surrounding buildings while the 900 orientation is the most comfortable orientation because it gets the longest exposure to solar radiation compared to the other orientations. Corridors with high $\mathrm{H}$ / W ratio $(\mathrm{H} / \mathrm{W}=2)$ and orientation $0 \mathrm{o}$ are the most comfortable conditions compared to the $\mathrm{H}$ I W ratio and other orientations.

The application of vegetation in improving thermal comfort is more effective than changing the canyon geometry. However, the application of vegetation will be more effective if it is applied in accordance with the geometry of the canyon. The effectiveness of the arrangement of vegetation in urban space is strongly influenced by canyon geometry, especially the $\mathrm{H} / \mathrm{W}$ ratio and orientation. The most effective 
The Effect of Vegetation in Various Canyon Geometry on The Thermal Comfort of Jakarta

Bayu Krisna Suryantara, Jatmika Adi Suryabrata, Alexander Rani Suryandono

87

arrangement of vegetation is applied to canyons with low $\mathrm{H} / \mathrm{W}(\mathrm{H} / \mathrm{W}=0.5)$ compared to canyons with high $\mathrm{H} / \mathrm{W}(\mathrm{H} / \mathrm{W}=2)$. Road corridors with a high $\mathrm{H} / \mathrm{W}$ ratio $(\mathrm{H} / \mathrm{W}=2)$ of 1350 orientation are strongly recommended to apply vegetation, especially trees with wide canopies. In corridors with high $\mathrm{H} / \mathrm{W}$ ratio, the application of vegetation is more effective for corridors with a orientation of 900 compared to other orientations. The application of grass, greenroof and greenwall is less effective in increasing the comfort of outdoor space. and greenwall provide a minimal reduction in PET value. The application of vegetation in the form of greenroof intensive and trees has a significant influence in decreasing the value of PET, Ta and MRT. The difference in the width of the tree canopy is very influential in decreasing the value of PET, Ta and MRT.

\section{References}

Ali-Toudert, F \& Mayer, H. (2005). Thermal comfort in urban street with pohons under hot summer conditions. Proc. 22th Conference on Passive and Low Energy Architecture (PLEA), Beirut, Lebanon. 1316 Nov. 2005, Vol. 2. pp. 699-704.

Ali-Toudert, F \& Mayer, H. (2007). Effects of asymmetry, galleries, overhanging facades and vegetation on thermal comfort in urban spohont canyons. Solar Energy, Vol. 81, pp.742-754

Bourbia, F. Awbi, H.B. (2004). Building cluster and shading in urban canyon for hot dry climate Part 1: Air and surface temperature Measurements. Renewable Energy. Vol 29, pp. 249-262.

Bourbia, F \& Awbi, H.B. (2004). Technical note: Building cluster and shading in urban canyon for hot dry climate Part 2: Shading simulations. Renewable Energy. Vol 29, pp 291-301.

Bruse, M. (2006). ENVI-met 3 - a three dimensional microclimate model. Ruhr University at Bochum, Geographischer Institut, Geomatik. Retrieved from: http:// www.envimet.com.

Emmanuel, R. Rosenlund, H. Johansson, E. (2007). Urban Shading - a design option for the Tropics? A Study in Colombo, Sri Lanka. International Journal of Climatology, Vol.27.

Givoni, B. (1998). Climate Considerations in Building and Urban Design. John Wiley \&
Sons, Inc: New York.

Groat \& Wang. Architectural Research Methods. John Wiley \& Sons Inc, USA. 2002.

Hwang, R.L., Lin, T-P., \& Matzarakis, A. (2011). Seasonal effects of urban street shading on long-term outdoor thermal comfort. Building and Environment. Vol 46, pp. 863870.

Johansson, E. (2006). Influence of Canyon Geometry on outdoor thermal comfort in a hot dry climate: A study in Fez, Morocco. Building and Environment, Vol 41, pp. 1326-1338.

Jusuf, K.S., Wong, N.H., (2009). Development of Empirical Model for an Estate Level Air temperature Prediction in Singapore. LBNL Berkely.

Jusuf, K.S., Wong, N.H., Hagen, E., Anggoro, R., Hong, Y. (2007). The influence of land use on the urban heat island in Singapure. Habitat International, Vol 31, pp. 232-242.

Koerniawan, M. D., Gao, W. (2015). Thermal Comfort Investigation in Three Hot-Humid Climate Theme Parks in Jakarta. American Journal of Environmental Sciences.

Paramita, B., Fukuda, H., (2014). Assessment of Flat in Bandung, Indonesia: An Approach to Outdoor Thermal Comfort at Hot-Humid Tropical, BauSIM.

Sharmin, T \& Koen, S. (2013). Effect of Canyon Geometry on Outdoor Thermal Comfort: A case-study of high-density, warm-humid climate. PLEA2013 - 29th Conference. Sustainable Architecture for a Renewable Future, Munich, Germany10-12 September 2013.

Shashua-Bar, L., Hoffman, M.E. (2000). Vegetation as a climatic component in the design of an urban spohont: an empirical model for predicting the cooling effect of urban green areas with pohons. Energy and Buildings, Vol 31, pp. 221-235.

Soegijanto, (1999), Bangunan di Indonesia dengan Iklim Tropis Lembab Ditinjau dari Aspek Fisika Bangunan. Direktorat Jenderal Pendidikan Tinggi Departemen Pendidikan dan Kebudayaan.

Wei, Y. (2014). Outdoor Thermal Comfort in Urban Space in Singapore. PHD Thesis. National University Singapore. 